\title{
Lessons from Grenfell: Poverty propaganda, stigma and class power
}

\author{
Tracy Shildrick
}

\begin{abstract}
The Grenfell Tower fire that took place in a council owned high-rise housing block in the early hours of $14^{\text {th }}$ June 2017 in the London Borough of Kensington and Chelsea represented the worst fire in Britain for many decades. This paper draws, in part, on the example of Grenfell Tower to interrogate some of the most pressing issues of our time around poverty, inequality and austerity. After a period of quiet, poverty now features more regularly in popular and political conversations. This is, in part, due to the proliferation of foodbanks that in many ways have become the public face of poverty in contemporary Britain.

Additionally the increased popularity of so called 'poverty porn' exemplified by programmes such as Benefit Street have provoked public and political debate about the relaities of poverty and its causes and consequences. Punitive policies towards out of work benefits claimants, austerity measures and the proliferation of low paid and insecure work mean poverty has been extended to more and more people, yet at the same time it is a condition that is frequently stigmatised, misrepresented and misunderstood. Whilst evidence shows increased stereotyping and stigmatisation of those experiencing poverty and other related disadvantages, there is also evidence that the British general public on the whole tend to care about fairness, equality of opportunity and that they dislike extremes of income and wealth, although importantly they also generally underestimate the realities of both. It was these extremes of inequality that Grenfell thrust so violently into the public imagination with many newspapers visually capturing the gulf between rich and 'poor' in their pictures of the burnt out shell of Grenfell set against a typical block of luxury apartments of the sort that are proliferating in London and other cities in Britain and that, particularly in London, often cost in excess of a million pounds or more. This paper looks at examples of how critical work is being done by those in power to manipulate and frame the terms of the discussion around poverty, inequality and economic insecurity and its causes and its consequences.
\end{abstract}

Key words - poverty, power, inequality, stigma 


\section{Introduction}

From the top floors of the 24-storey Grenfell Tower, residents could see out across Kensington and Chelsea, one of the wealthiest local authorities in the country. Yet the tower and its residents were situated in one of the most deprived areas in England. The Borough is one of London's most unequal with extreme poverty and wealth living side by side (Barr 2017, The Guardian, $15^{\text {th }}$ June)

I would feel very resentful if those people got this for free. My husband and I work very hard to afford this. I would move out. Why should they get this for free (Female caller to a talk show on LBC radio after the Grenfell disaster when it was revealed that a small number of those affected might be rehoused in the 'affordable' housing segment of a nearby luxury block of flats radio $22^{\text {nd }}$ June 2017)

The fire at Grenfell Tower in the London Borough of Kensington and Chelsea on $14^{\text {th }}$ June 2017 was the worst fire disasters in the UK for decades ${ }^{1}$. The fire disaster brought into critical, and at times distinctly visual relief, some of the extremes of economic inequality as well as some of the lived effects of austerity, that characterise daily life in contemporary Britain for many people. The visual images of luxury tower blocks and the haunting images of the burnt out shell of the Grenfell Tower were writ large across many of the newspapers, with the accompanying headlines of 'A tale of two cities' speaking for themselves of the gross levels of economic inequality that characterise the Greater London Borough of Kensington and Chelsea. Yet, whilst London is a city that embodies extremes of wealth and poverty - and everything in between - the disparities of life conditions and life chances that characterise the lives of those who live there are mirrored up and down the county to a greater or lesser degree (Hood and Waters 2017). This paper is primarily concerned with poverty and inequality in Britain and the UK more broadly (similar agendas have been pursued countries such as US, Canada and Australia as well as many western European

\footnotetext{
${ }^{1}$ It is difficult to find the right terminology to describe the Grenfell Tower fire. Commentators have used various terms, including 'disaster', 'catastrophe' and some arguing that 'crime' is a more accurate description. For the purposes of this paper the word disaster will be used despite its limitations
} 
countries). Successive British governments have pursued a particularly aggressive neoliberal agenda of deliberately deepening inequalities since the Thatcher government of the 1980s. Since 2010 the policy of austerity that has been vigorously pursued by successive Conservative led administrations have led to deepening divisions and particularly unforgiving life conditions for those who are economically marginalised (Cooper and Whyte 2017; O'Hara 2017; Dorling 2017; Pring 2017; O'Connell and Hamilton 2017). Whilst these trends are not particular to the UK there is little denying that the inequality agenda has been pursued with such vigour in the UK that it is now one of the most unequal countries in the developed world (The Equality Trust 2017). Rather perversely and running parallel to these political and policy trends, those on the lowest incomes or who experience poverty and / or other multiple forms of deprivation and structural limits to their life opportunities over which they have no control, have been demonised and misrepresented and are frequently portrayed in both popular and political terms as being feckless and failing to aspire or work hard enough or to be willing to work at all (MacDonald et al 2013; Jensen 2014; Jensen and Tyler 2015; Wright 2015). Here and elsewhere (Shildrick 2018) I argue that these misleading, damaging and divisive depictions of those experiencing poverty and related disadvantages might best be described as poverty propaganda. In contemporary Britain poverty propaganda works to stigmatise and label those experiencing poverty and related disadvantages and thus effectively hides the real causes and consequences of poverty. Poverty propaganda has both real and ideological effects. Punitive and divisive policies towards poverty become more palatable - and even desired - by a general public who on the whole tend to accept that such responses are just, acceptable and in many cases necessary (British Social Attitudes 2016). The narratives contained within poverty propaganda - that those experiencing poverty are workshy, lazy and culpable for their own 
predicaments - are so powerful, pervasive and persuasive that even people experiencing deep poverty often subscribe to their truth (Shildrick and MacDonald 2013). Yet attitudes towards inequality, poverty and economic disadvantage are complex and multi-layered. People on the whole tend to underestimate both the extent of extreme wealth (The Equality Trust 2017) as well as the relentless and significant everyday hardships that characterise life for those experiencing poverty (Shildrick 2018 and 2018 forthcoming). Even those in the top $1 \%$ of the wealthiest people in the UK tend to express views that downplay their wealth and privilege (Hecht 2017).

Yet, episodes such as Grenfell Tower have the potential to disrupt some of this shamelessly disparaging and derogatory rhetoric around poverty, proving its deceit and aptly illustrating the vast crevice that exists between rhetoric and reality. The paper has three main parts: the first outlines the current economic and political context in the UK and looks at the role of stigma and shame and the importance of poverty propaganda in perpetuating particular views around poverty and disadvantage. The following section explores the Grenfell fire disaster in a little more detail and argues that both overtly, and in more subtle ways, the disaster not only epitomises so much that is unfair and divisive with neoliberal capitalism, but the disaster - if one looks closely enough - also reveals the shameless dishonesty of poverty propaganda. The final substantive section attempts to understand some of the issues raised in the paper and offers some reflections on why poverty propaganda is so successful. 


\section{Inequality, policies that hurt and the power of poverty propaganda}

In 2014 Picketty published his highly influential book 'Capital in the Twenty First Century'. In it he argued that:

For millions of people 'wealth' amounts to little more than a few weeks' wages in a checking account or low-interest savings account, a car and a few pieces of furniture. The inescapable reality is this: wealth is so concentrated that a large segment of society is virtually unaware of its existence, so that some people imagine that it belongs to surreal or mysterious entities (2014: 259)

One of the major conclusions of Picketty's work was that those with economic resources were benefitting most from the way most capitalist societies were organised resulting in gross economic inequalities. Some social scientists have expressed dismay at both the scale of inequality in Britain and its consequences for most citizens and for society more broadly (Wilkinson and Pickett 2010; Dorling 2014, 2015, 2017). In Britain today, the richest 1,000 people own more wealth than $40 \%$ of households, or 10.2 million families. In the last year alone the combined wealth of Britain's 1,000 richest people increased by $£ 82.5$ billion to a barely believable $\mathrm{f} 658$ billion (Equality Trust 2017). In recent years increasing attention has been devoted to the top $1 \%$ who have disproportionately high incomes in comparison to those beneath them (Dorling 2014; Hecht 2017). The High Pay Centre points out that a Chief Executive can take home more in three days than one of their employees can earn in a whole year (High Pay Centre 2015). The 'UK now have more billionaires per capita than any other country in the world, but London is now far and away the city with the greatest number of sterling billionaires resident globally - some 72 (compared to Moscow with 48, New York with 43, San Francisco with 42, Los Angeles with 38 and Hong Kong with 34)' (Burrows et al 2017: 189). 
In contrast to this explosion of wealth at the top, poverty has been increasing at a dramatic rate as a direct result of punitive policies directed towards those experiencing poverty and disadvantage in the UK (Hood and Waters 2017). These trends towards increasing inequality have been in train for over forty years so it would be wrong to blame any one political party entirely but since the election of the Coalition government led by the Conservatives in 2010 and the subsequent election of two Conservative administration's (albeit in 2017 the current one being propped up by an uneasy alliance with the Democratic Unionist Party) successive policy developments, particularly in respect of cuts made in the name of austerity, have been explicitly deployed that worsen the economic position of those on the lowest incomes (Taylor-Gooby 2013; 2017). Poverty in the UK is widespread and has two main causes. Firstly, paid employment that is either insecure and/ or low paid and that is proliferating in the UK and that does not take people away from poverty either far enough or for long enough to make a real difference to their lives (Shildrick et al 2012a). It is particularly telling that in the UK the majority of households experiencing poverty now have at least one member in paid employment (JRF 2016). Secondly, poverty is caused by inadequate financial support for out of work benefit claimants (Padley and Hirsch 2017). Cuts to out of work benefits have been a key priority since 2010 with those forced to rely on out of work benefits faring particularly badly and being forced to engage with a punitive and hostile system that not uncommonly leaves people destitute whereby they are left for not insignificant periods of time without any income at all (Fitzpatrick et al 2016). Disabled and sick people have been subjected to degrading assessments through the increased use of Work Capability Assessments which Pring describes as 'possibly the most violent and discriminatory tool ever handed to a government department' (2017: 51). Whilst set ups like ATOS (the company initially responsible for assessing disabled people and determining 
whether they were entitled to sickness benefits) profited from a $£ 400 \mathrm{~m}$ government contract for its trouble whilst vulnerable, sick and disabled people were forced to endure intrusive and cruel and all too often completely incompetent assessments that left all too many declared 'fit to work' (many cases subsequently overturned on appeals), without essential benefits and at worse, left destitute, and in some cases to die not only without dignity but also sometimes without food in their bellies (Fitzpatrick et al 2016; Ryan 2015; Garthwaite 2016). What Mills refers to as 'austerity suicides' have become all too commonplace (Mills 2016) and financial strains add to a rising tide of mental ill health (O'Hara 2017). In June 2016 the United Nations ruled that UK welfare reforms and austerity measures were in breach of international human rights (UN 2016).

Yet poverty and economic disadvantage are rarely called out as being the result of policy and political decisions but is rather presented (and thus largely understood by many people) to be the result of individual behaviours. Poverty propaganda is produced via political speak, policy documents and reinforced by the media, both print and television. The production of programmes such as Benefit Street and Life on the Dole work to present a partial, highly edited and spectacular (if generally somewhat entertaining) depiction of how people on out of work benefits or experiencing multiple problems and disadvantages live their lives (Tyler 2015; Jensen and Tyler 2015; MacDonald and Shildrick 2014). Furthermore disparate groups, from rioters, so called 'Troubled Families' and those with problematic drug and alcohol problems, can be drawn in at various moments to bolster notions of fecklessness and irresponsibility amongst those experiencing poverty and related disadvantages (Tyler 2013; Shildrick and MacDonald 2013). 'Welfare' in the form of out of work benefits is placed centre stage in the production of poverty propaganda despite the fact that out of work 
benefits make up only a small proportion of the welfare bill (Hills 2015) and out of work benefits provide only a very limited income (Padley and Hirsch 2017). In their attempts to garner what calls 'anti-welfare common sense' (Jensen 2014) political figures and the media deploy rare, unusual and at times, downright fantastical stories of supposed problematic behavior of varying sorts that is purported to be supported by the welfare state. These examples are often carefully timed and deployed in unison to ensure the message is received and to invoke public outrage towards the welfare state and those in receipt of out of work benefits (Jensen 2014; Allen et al 2015; Jensen and Tyler 2015). The pervasiveness and consistency of poverty propaganda's core messages (even if the language changes with the political climate of the day), that those experiencing poverty are somehow culpable for their own poverty, means that the realities of poverty and its causes and consequences continue to be clouded out. All of this means that episodes like the Grenfell Tower disaster can appear, and are sometimes explicitly used and positioned, to confirm rather than disrupt poverty propaganda. It is to the details of the fire and its aftermath that this chapter now turns

\section{The Grenfell Tower Disaster and the dishonesty of poverty propaganda}

The polar extremes of inequality that exist in contemporary that Britain were most vividly and violently thrust into the public imagination by the Grenfell Tower disaster. In many respects the fire exposed many of worst aspects of contemporary neo-liberal capitalism, not just in terms of inequality and social housing, but also in the ways that profits can be put before people's lives and well-being and how cuts to public services such as the police and fire service, made in the name of austerity, can have deadly consequences. The Grenfell tower was situated in the Borough of Kensington and Chelsea that is one of the wealthiest 
Boroughs in London but it also has significant levels of poverty. Around one fifth (19\%) of children living in Kensington and Chelsea are considered to be living in income-deprived households. In the north of the borough close to half of all children live in income deprived households (Trust for London 2017). On the night of the fire, a fridge cause the initial blaze that was initially contained to one flat but rapidly spread, very quickly engulfing the whole building. The Metropolitan Police have reported that the official death toll is likely to remain at seventy plus one unborn baby (BBC news 2017). Many residents perished on the highest floors of the building where they had tried to seek refuge from the rapidly advancing flames, many adhering to the safety advice to remain in their flats in the event of a fire and the initial advice of the emergency services on the night. Those who escaped the Grenfell Tower lost family members, neighbours and friends along with all of their possessions. At the time of writing, just over nine months on from the disaster, the trauma for those directly affected inevitably continues. Very few families have been offered suitable, permanent accommodation and by the time of the one-year anniversary of the fire many families will remain in temporary accommodation. Indeed a the time of writing in March 2018 only sixty two of the two hundred and nine households have moved into new permanent accommodation (Walker 2018). Funds that have been raised to help those affected have largely have been very slow to be released to those in need, and hundreds of people in the area have been referred to mental health services for severe anguish and distress (Rose 2017).

Places like Grenfell Tower, predominantly social housing (twelve of the one hundred and twenty flat were owned privately) managed by the local authority have a special place in the poverty propaganda described above (Hanley 2012; Garner 2011; MacKenzie 2015). Political 
figures are fond of referring to 'left behind' estates' (Cameron 2016) and perpetuating myths of despair and hopeless lives lived on 'estates where often three generations of the same family have never worked (Ian Duncan Smith 2007). As Slater (in this volume) argues the 'sink estate' has entered the political lexicon in order to condemn the very existence of social housing' and at the same time to blame 'poverty on the behavioural choices of tenants' (p11). Little wonder then that in the popular and public imaginary social housing has all too often become synonymous with the so-called 'sink estate' (Cameron 2016), purported to be inhabited by only the hopeless, the workshy and the criminal (Hanely 2007). Garner has described this generic stigmatisation of social housing 'Estatism', meaning 'the social dynamics associated with council estates and prejudice towards residents based on where they live' (2011: 1). The social housing tower block is particularly maligned. As Hanley points out that ' there is one phrase in the English language that has come to be larded with more negative meaning than 'council estate' and that is the 'tower block' (2012: 97). Despite these blanket negative portrayals of social housing, research with people living on council estates and in social housing shows that - despite the inevitable problems that blight areas where there are large concentrations of poverty- there is still often much that people value about their homes and their communities (MacKenzie 2015). Indeed it has been reported that many of the residents of Grenfell were keen to move into the flats and it was apparently the views of the London skyline that attracted two young people from Italy who had moved to London to work as architects and chose to live near the top of Grenfell Tower and they regularly posted snaps of the views from their home on social media (Di Donato and Narayan 2017). 
Yet there were clearly major structural shortcomings in the quality of the accommodation and the safety of the tower block. The limited and sometimes unsafe housing conditions available to those with limited financial options and resources have been, at times, laid uncomfortably bare. As Watt has points out in respect of Grenfell Tower, that it:

Has revealed the injustices, deprivations, expulsions and brutalities that are routine in the lives of ordinary, working class, multi-ethnic Londoners. These include: overcrowding; being 'regenerated' and watching your home and neighbourhood crumble around you: being shunted into unsatisfactory temporary accommodation; being displaced out-of-borough; being ignored and / or patronised by political elites; being invisible and not counting; and not even being properly counted...//...Disposable homes, disposable lives (2017)

Housing, particularly in London, has become a critical site of class struggle, whereby even those working in key services, such as the police or health services struggle to access suitable housing and have virtually no chance of buying a home and research shows that parental wealth is becoming ever more crucial for young people to access their own homes (Hood and Joyce 2017). Housing options for those reliant on out of work benefits have been decimated, whilst expensive flats afforded only by the wealthy continue to proliferate (Watt 2017). Many serve as second, or even third or fourth homes and others are rented out to those who are reliant on the rental market, thus further benefitting the wealthy at the direct expense of those less fortunate. Many people with disabilities live in social housing, such as Grenfell, despite mobility issues that render them trapped when lifts are out of order and even more vulnerable in an emergency such as the Grenfell fire. Stories emerged after the Grenfell fire of a blind man rescued from the eleventh floor by the fire service and one disabled woman surviving after her son carried her down twenty-four flights of stairs (Springfield 2017). As Springfield points out 'there is no legal obligation on the part of the council workers to ensure that the disabled person can easily escape from their home 
in the case of fire' (Ibid). Ryan recently argued that around 1.8 million people are stranded in properties that are totally unsuitable for their needs and leaving many stranded unable to leave their properties (Ryan 2017).

Grenfell reveals the dishonesty of popular depictions of both poverty and of those who reside in social housing. The lists of the dead that emerged in the days and weeks after the fire, putting faces and lives that were lived, to the dead and missing, makes for difficult and painful reading even for someone personally unconnected to the disaster. Highlighting individual cases is difficult. Grenfell was home to the young and the old, multiple generations of the same families, working-class Londoners who had lived there for decades and those newly arrived, seeking sanctuary from their own war torn homes in places like Syria. Shelia (previously known as Sheila Smith) was an eight-four year old grandmother, described as a poet, artist and philosopher and an active member of the community. She died on the night of the fire and left behind two sons, six grandchildren and three great grandchildren (Rawlingson 2017). The two young Italian architects - who so publically and enthusiastically celebrated and shared their home - also died. They had moved to London to take up jobs as assistant conservation architects, one of whom Gloria Trevisan, was described by her employer as 'an extremely promising and talented graduate' (Braidwood 2017). The first victim of the fire to be named, Mohammad Alhajali, had fled from Syria with his brother Omar who survived the fire after being rescued, was at the time of his death studying civil engineering at the University of West London (Forster 2017). It is perhaps the issue of paid employment that stands out as most instructive in the Grenfell disaster. Poverty propaganda rests upon the notion that people experiencing poverty are workshy. The divisive and damaging caricature of the welfare cheat, faring well on benefits, obscures 
the facts of everyday struggle where low-paid and insecure work is now a significant cause of poverty in the UK. It is a telling fact that:

'For the first time the majority of people in poverty are actually employment. The nature of poverty in Britain is changing. The idea of 'making work pay' increasingly sounds like an empty slogan to the millions of people who are hard-pressed and working hard, often in two or three jobs and struggling to make a living' (Sentamu 2014: 4)

As the details about individuals killed in Grenfell Tower it is clear to see that it housed many people who worked or who were retired but had previously been in paid employment. This is a simple point but it is very important. Everyday ordinary workers, many of who keep London functioning as one of the most economically vibrant and vital cities in the world, lived in Grenfell and many like them live in social housing up and down the county. Feeders, cleaners and carers all lived in Grenfell, and continue to live in places just like it. The man who lived in the flat where the fire started was reported to work as a taxi driver (ClarkeBillings 2017). Other victims have been emerged to be a 'retired lecturer', a 'teaching assistant' and consultancy firm was widely reported in the media as seeking information on one of their employees who had not been seen since the fire (Rawlingson 2017). Red Consultancy, an award winning public relations (PR) company posted on social media that they were worried about Mo Tucca who was missing after the fire and later confirmed to have died. They posted on Twitter on $31^{\text {st }}$ July 'today marks ten years since our friend Mo, a victim of the Grenfell fire, joined Red. Out of love and respect today we will close at 4pm' (Red Consultancy pinned tweet). A BBC report for Newsnight (27 $7^{\text {th }}$ September 2017) reported on the $21^{\text {st }}$ floor of the tower and its resident's experiences on the night of the fire, highlighting the diversity of those who lived on just that floor. One woman was reported to be retired having worked previously as a nanny and in a café. All of the other residents on 
that particular floor were reported to be working, in jobs as diverse as IT management consultancy, a beautician and beauty salon owner, a hospital porter and a civil engineer. One of the most widely reported deaths in the days that followed the fire was that of Khadija Saye, a promising young photographer whose work had been exhibited in Venice. An obituary from one of her tutors reads:

Born in London, Saye lived and worked on the 20th floor in Grenfell Tower with her Gambian mother, Mary Mendy (who is also missing, and presumed dead). Saye was educated locally until age 16 , when she won a full scholarship to the prestigious Rugby School; she went on to take a BA in photography at UCA Farnham, where she started to make work on identity and her Gambian heritage. She began documenting Grenfell Tower while still a student, for example; her final series, for her graduation in 2013, looked at Afro-Caribbean hairstyles and was titled Crowned (Smyth 2017).

A more fulsome study of the lives lived and lost at Grenfell would be worthy and instructive in its own right (although the truth of this is likely never to be properly known) but even on this short assessment it is very clear that Grenfell housed many ordinary - and extraordinary - people. We shouldn't be surprised by this. Rather than some distinct 'other' (Lister 2004), those experiencing poverty make up an increasingly significant proportion of everyday citizens in one of the richest countries in the world. $28 \%$ of children in the UK are growing up in poverty with the figure rising all the time (JRF 2016). Furthermore, it is remarkably telling that the majority of families experiencing poverty also have at least one member in a job (Ibid). Quite simply, those experiencing poverty tend to be workers, not shirkers, who all too often find themselves cycling in and out of low paid, insecure jobs and on and off 'welfare' (Shildrick et al 2012a). Official unemployment rates in Kensington and Chelsea are relatively low at $5 \%$ but research shows that $16 \%$ of people in the Borough are paid below the so called 'living wage' (Trust for London 2017). Perhaps unsurprisingly and in contrast to the popular and political stigmatisation of places like Grenfell, the tower housed the 
working class. People who were all too often working and who resided in one of the richest cities in the world, and who were linked by a state that failed them in the cruelest way possible.

\section{Discussion: poverty propaganda and stigma as class power}

This section of the paper draws together some of the issues outlined above and reflects on both the impact and purpose of poverty propaganda and the ubiquitous stigma that has been explicitly and deliberately attached to poverty in the current context. Poverty propaganda is given voice, and hence power, though the mainstream media, in ways that hard evidence about poverty or the grind of day to day life in low paid, insecure work that fails to take people away from poverty, either far enough or for long enough, to make a real difference to their lives, very rarely is. It is most often the affluent and the powerful (and in many cases those who have the power to resolve poverty or extend the condition to more and more citizens) who hold the cards about how poverty is presented in public arenas. The voices of those with first hand experience are very rarely heard or where they are, they are moulded, shaped and represented in particular ways. For example in television programmes such as Benefit Street which claim to be true to life representation of unemployment and poverty, depictions are partial and prone to extremes rather than the everyday and the mundane. The footage shown in such programmes is specifically orchestrated to present the participants in the programmes very much as the irresponsible and feckless 'other'. Whilst even those experiencing deep poverty and related disadvantages can often subscribe to the truth of poverty propaganda, research also shows that the same people are rarely oblivious to the inequity in their life opportunities and conditions (Savage 2015; Shildrick et al 2012b; Shildrick 2017). Evidence shows that people experiencing poverty frequently feel ignored, 
not listened to and powerless to challenge decisions that are made about their lives. There is not space in this piece to talk about the vote to leave the European Union that occurred in 2016 in any detail but there is clear evidence that for some people a feeling of being denied the economic benefits of capitalism and a feeling of concerns not being listened to or taken seriously was a factor in some people's decision to vote to leave (Goodwin and Heath 2016). Speaking of the shock election of Donald Trump in the US in 2016 (a development that has similarly been reported to be a result of the supposedly 'left behind' white working class) Reeves argues that 'years of work lie ahead for social scientists picking over the data and trends' (Reeves 2017:2) and the same is certainly true of the vote to leave the EU in the UK. But what is becoming increasingly clear is that significant swathes of the population are not benefitting from neoliberal capitalism in the ways they have been led to believe and that people and perhaps most importantly, are rarely completely oblivious to the unfairness of their live experiences and life chances (2017). What poverty propaganda does is to produce confusion about the root cause of inequality, relegating poverty the preserve of the feckless, the lazy and the workshy.

The disconnect between poverty and wealth and bodies of power and powerlessness was thrown into sharp relief after the Grenfell Tower disaster as residents and those directly affected by the fire expressed their anger and frustration with the Council when it came to light that they had previously been warned that many residents had concerns about the safety of the tower block. The Grenfell Tower disaster the Grenfell Action Group had just back in November 2016 warned about 'dangerous living conditions' and concluded that 'it is a truly terrifying thought but the Grenfell Action Group firmly believe that only a catastrophic event will expose the ineptitude and incompetence of our landlord, the 
KCTMO' (Grenfell Action Group 2016). Residents felt that their concerns were not listened to and evidence shows that whether these concerns were heard or not, they were never acted upon. This disconnect between power, privilege and powerlessness was further exemplified by the rather telling admission from the new leader of Kensington and Chelsea Council that she had never actually been inside any of the high rise tower blocks in the Borough before the fire (Rawlingson and Bowcott 2017). The launch of the enquiry into the fire (and of which residents and campaigners have been highly critical both in terms of its remit and its leadership) was held in the palatial De Vere Grand Connaught Rooms in Covent Garden. The obvious and overt irony of this choice of meeting venue with its 'ornate ceilings, beautiful wood panelling and ornate chandeliers' (De Vere Connaught Rooms 2017) was not lost on the residents who attended the meeting, as Emma Dent Coad MP said of the venue:

We were sitting in a ballroom, dripping with chandeliers. It's the most incredibly inappropriate place. Clearly, the judge felt perfectly comfortable in a place like this a lot of people didn't. People feel it was deliberate, to intimidate and make people feel unimportant and looked down on (2017)

People experiencing poverty are rarely immune to its negative effects and the limits in places on their life chances and opportunities. Yet the real causes of poverty, its life limiting effects and the role governments play in perpetuating or alleviating poverty and its effects remains largely hidden by false and misleading caricatures about poverty and the people who experience it. The importance of low paid and insecure work and inadequate out of work benefits rarely feature in the public and political debate. Furthermore the ubiquitous 
nature of poverty propaganda means that punishing, cruel and sometimes illegal, policies can be wrought towards those experiencing poverty and other disadvantages with relatively little dissent and in many cases acceptance or outright support. Thus poverty propaganda plays a crucial role in encouraging consent for and legitimising a political and economic system that further disadvantages some whilst continuing to advantage others. Link and Phelan argue that, 'When people have an interest in keeping other people down, in or away, stigma is a resource that allows them to obtain the ends they desire. We call this resource stigma power' (2014: 24). Tyler has also powerfully documented the ways in which stigma is increasingly utilised as a mechanism for the exercise and imposition of power by those with and in power against those without it (see this volume and 2017). The power of stigma, particularly as it has been developed and used to negatively label those experiencing poverty and other related disadvantages, plays a significant role in fostering a climate of distrust and a propensity to distance oneself from people at the lower end of the income scale, promoting a view of disadvantaged groups of people as 'the other' (Lister 2004) and in one way or another culpable for their own predicaments. Such is the power of stigma and shame that is now closely associated with poverty that even those experiencing deep poverty tend to disassociate themselves from the condition. Whilst the idea that proportions of those experiencing poverty are undeserving or culpable for their experiences is nothing new (Welshman 2013) in the current climate, such is the power and pervasiveness poverty propaganda that virtually anyone forced to rely on out of work benefits is now perceived to be feckless and undeserving (Allen et al 2015; Shildrick et al 2012b; Shildrick and MacDonald 2013; Jensen and Tyler 2015). Despite widespread understand of the unfairness of life conditions amongst those who are economically marginalised, poverty propaganda is so powerful and effective at manufacturing confusion 
about the root causes of deepening structural inequalities, that it aids the deepening of gross structural inequalities to be perpetuation both perpetuated over time and tolerated as being inevitable and just and deserved. As such poverty propaganda is a powerful political tool that orchestrates widespread consent for a political system that affords punishing life opportunities for significant numbers of its citizens whilst continuing to bolster the weight and strength of the cushions that protect the few. Neoliberal capitalism operates in this way and poverty propaganda plays an important role in its legitimation, normalising class inequality and helping to ensure its continuation. Inequalities of life chances and life conditions are presented as right, necessary and just. Even those experiencing deep poverty can be seduced by its messages, despite vehemently, and quite justifiably, rejecting such narratives as in any way reflective of their own lives and experiences (Shildrick and MacDonald 2013).

\section{Conclusion}

Poverty propaganda works to orchestrate confusion and muddies the waters about both the causes and the consequences of poverty in Britain today. Hence it works to create misunderstanding and to hide the realities and who and what are responsible for poverty and its effects in limiting the life opportunities and life chances of many citizens. Whilst there might be growing disquiet about some of the issues discussed in this paper and in particular about the on-going commitment to austerity and its impact on public services there is, as yet, no clear consensus. Whilst there is evidence to suggest that many people, particularly those experiencing multiple and place based disadvantages associated with decades of deindustrialisation and the degradation of working class employment opportunities, recognise all too well that their lives are blighted by limited opportunities 
that are beyond their control, poverty propaganda works to distil blame and create confusion as to how and why such inequalities persist. Hence poverty propaganda is politically valuable and vital because it plays a critical role in legitimising punitive policies towards those experiencing poverty and other forms of disadvantage, whilst at the same time helping to legitimate and normalise extremes of inequality. The stigmatising narratives that make up poverty propaganda are often found to be particularly alive in deprived neighbourhoods, whereby even those in deep poverty will (quite correctly) reject scrounger narratives as bearing any relation to their own lives, problems and struggles, but vehemently believe that others in their streets or neighbourhoods exactly fit such a label (Shildrick et al 2012a; Shildrick and MacDonald 2013). The role of government's in fostering gross levels in inequality and inflicting sometimes dire living conditions on some of its most economically marginal citizens is permitted to go if not unseen, as at least justifiable, and due to the belief in the supposed preponderance of individual feckless and irresponsible behaviour. The role that poverty propaganda plays in stigmatising whole swathes of the population, from those living in social housing tower blocks such as Grenfell Tower, to those claiming out of work benefits, to those experiencing any number of social and economic disadvantages, allows poverty propaganda to work particularly effectively. Poverty propaganda is a form of stigmatisation that damages those with the least and provides a critical resource for those with power. In many respects the disaster at Grenfell Tower shone a very vivid and at times, viscerally visual light on many of the most pressing political issues of the current time. The people who died in the Grenfell Tower or have been affected by the disaster, were victims of a neoliberal regime that inevitably produces casualties and losers along with its winners. Those people join a long and growing list of casualties subjected to sometimes illegal and unnecessarily cruel policies that are deliberately inflicted 
on those with the least by those with the most. Perhaps most shamefully of all, this all takes place in one of the richest countries in the world.

\section{References}

Allen, K., Mendick, H., Harvey, L. and Ahmed, A. (2015) 'Celebrity Motherhood and the cultural politics of austerity' Feminist Media Studies, 15, 907 - 925

Barr, C. (2017 June 15) 'Wealth and poverty sit side by side in Grenfell Tower's borough' The Guardian

BBC news (2017, November 16). Grenfell Tower final death toll stands at 71. Retrieved from, http://www.bbc.co.uk/news/uk-42008279

(last accessed 2 May 2018)

BBC Newsnight (2017) Grenfell Tower: the 21 ${ }^{\text {st }}$ Floor

http://www.bbc.co.uk/programmes/p05hfh6m (Last accessed 2 May 2018)

Braidwood, E. (2017, June 23) 'Two architectural assistants believed dead in the Grenfell tragedy' The Architects Journal $23^{\text {rd }}$ June 2017. Retrieved from

https://www.architectsjournal.co.uk/news/two-architectural-assistants-believed-dead-ingrenfell-tragedy/10020857.article (Last accessed 2 May 2018)

British Social Attitudes (2016) British Social Attitudes 2016 London, Natcen

Burrows, R., Webber, R., and Atkinson, R. (2017) 'Welcome to 'Pickettyville'? Mapping London's Alpha Territories Sociological Review Vol 65 (2) pp184 -201

Cameron, D. (2016, January 1) New Years Day address, $1^{\text {st }}$ January 2016 
Clarke-Billings, L. 2017, June 15) 'Grenfell Tower resident 'whose fridge started the deadly blaze' identified as taxi driver Dad' Daily Mirror Retrieved from

http://www.mirror.co.uk/news/uk-news/grenfell-tower-resident-whose-fridge-10623522

(Last accessed 2 May 2018)

Cooper, V. and Whyte, D. (Eds) (2017) The Violence of Austerity London, Pluto Press

Dent Coad, E. (2017, September 14). Sitting in a ballroom dripping with chandeliers. BBC News

De Vere Connaught Rooms Promotional web pages (2017) Retrieved from

https://www.phcompany.com/de-vere/grand-connaught-

rooms/?utm source=google\&utm medium=local\&utm campaign=localSEO

(Last accessed 2 May 2018)

Di Donato, V. and Narayan, C. (2017, 17 June) London fire victim was on 'phone with parents when she died, says lawyer CNN news

Dorling, D. (2014) Inequality and the 1\% Verso London

Dorling, D. (2015) Injustice Bristol, Policy Press

Dorling, D. (2017) 'Austerity and Mortality in Cooper, V. and Whyte, D. The Violence of Austerity (pp 44-50) London, Pluto Press

Duncan-Smith I (2007) Breakthrough Britain: Ending the Costs of Social Breakdown. London:

Centre for Social Justice 
The Equality Trust (2017a) Equality matters to human rights. We need a socio-economic duty London, The Equality Trust https://www.equalitytrust.org.uk/equality-matters-humanrights-we-need-socio-economic-duty

(Last accessed 2 May 2018)

Equality Trust (2017b) Scales and Trends London https://www.equalitytrust.org.uk/aboutinequality/scale-and-trends

(Last accessed 2 May 2018)

Fitzpatrick et al (2016) Destitution in the UK York, JRF

Forster, K. (2017, June 16) ‘Grenfell Tower Fire victim's last 'phone call to brother: 'why did you leave me?' The Independent $16^{\text {th }}$ June 2017

Garner, S. (2011) White working class neighbourhoods: Common themes and policy suggestions York, JRF

Garthwaite, K. (2016) Hunger Pains: Life inside foodbank Britain Bristol, Policy Press Goodwin, M. and Heath, O. (2016) Brexit vote explained: low skills and lack of opportunities York, JRF

Grenfell Action Group (2016, November 20) KCTMO - Playing with fire! November 2016 https://grenfellactiongroup.wordpress.com/2016/11/20/kctmo-playing-with-fire/(Last accessed 2 May 2018)

Hanley, L. (2012) Estates: An intimate history London, Granta books 
Hecht, K. (2017) A Relational Analysis of Top Incomes and Wealth: Economic Evaluation, Relative (Dis)advantage and the Service to Capital London, LSE

http://www.Ise.ac.uk/International-Inequalities/Assets/Documents/Working-

Papers/Katharina-Hecht-A-Relational-Analysis-of-Top-Incomes-and-Wealth.pdf

High Pay Centre (2015) Thinking high and low: Exploring pay disparities in society London, High Pay Centre

Hills, J. (2015) Good times, bad times: the "welfare" myth of them and us Bristol, Policy Press

Hood, A. and Joyce, R. (2017a) Inheritances and inequalities within and across generations London, UK: Institute for Fiscal Studies

Hood, A. and Waters, T. (2017) Living standards, poverty and inequality in the UK: 2016-17 to 2021- 2022, London, UK: Institute for Fiscal Studies

Jensen, T. (2014) 'Welfare, commonsense, poverty and doxosophy Sociological Research on Line 19, 3

Jensen, T. and Tyler, I. (2015) 'Benefit Broods': The cultural and political crafting of antiwelfare common sense Critical Social Policy 35 (4) pp470 - 491

Joseph Rowntree Foundation (2016) We can solve poverty in the UK York, JRF 
LBC Radio (2017) 'If Grenfell residents move into my flats, I will move out' LBC radio phone in $22^{\text {nd }}$ June 2017 http://www.lbc.co.uk/radio/presenters/shelagh-fogarty/if-grenfell-

\section{residents-move-into-my-flats-ill-move/}

Link, B. and Phelan, J. (2014) 'Stigma Power' Social Science and Medicine Vol. 103, February, pp $24-32$

Lister, R. (2004) Poverty, Cambridge: Polity.

MacDonald, R. and Shildrick, T. (2014) "Benefit Street' and the myth of workless communities Sociological Research on Line 19 (3) 1

MacDonald, et al (2013) 'In search of 'intergenerational cultures of worklessness': Hunting the yeti and shooting zombies' Critical Social Policy 34 (2) p199 - 220

McKenzie, L. (2015) Getting By: Estates, class and culture in austerity Britain Bristol, Policy Press

Mills, C. (2017) Suicides linked to austerity: From a psychocentric to a psychopolitical autopsy' Discover Society $1^{\text {st }}$ February

O’Connell, R. and Hamilton, L (2017) 'Hunger and Food Poverty' (pp 94 - 100) in Cooper, V. and Whyte, D. The Violence of Austerity London, Pluto Press

O'Hara, M. (2017) 'Mental Health and Suicide' (pp 35 -43) in Cooper, V. and Whyte, D. The Violence of Austerity London, Pluto Press 
Padley, M. and Hirsch, D. (2017) A minimum income standard for the UK in 2017 York, JRF

Piketty, T. (2014) Capital in the Twenty First Century Harvard University Press, United States of America

Pring, J. (2017) 'Welfare Reforms and the Attack on Disabled People' (pp 51-58) in Cooper, V. and Whyte, D. The Violence of Austerity London, Pluto Press

Rawlingson, K. (2017, November 27) The victims of the Grenfell Tower fire The Guardian, $27^{\text {th }}$ November ttps://www.theguardian.com/uk-news/2017/jul/13/grenfell-tower-firevictims-dead-missing-identified-named-so-far (Last accessed 2 May 2018)

Rawlingson, K. and Bowcott, O. (2017, July 12) ' Kensington and Chelsea council leader had never been inside its high rise flats' The Guardian $12^{\text {th }}$ July https://www.theguardian.com/uk-news/2017/jul/12/kensington-and-chelsea-leaderelizabeth-campbell-never-been-inside-high-rise-flats-grenfell (Last accessed 2 May 2018)

Reeves, R.V. (2017) Dream Horders: How the American upper middle class is leaving everyone else in the dust USA, Westchester Publishing

Rose, E. (2017, August 10) 'Hundreds from Grenfell Tower area referred to mental health services' The Evening Standard 
Ryan, F. (2014, September 9) 'David Clapson's awful death was the result of grotesque government policies' The Guardian $9^{\text {th }}$ September https://www.theguardian.com/commentisfree/2014/sep/09/david-clapson-benefitsanctions-death-government-policies

(Last accessed 2 May 2018)

Ryan, F. (2017, March 15 ) Trapped: the growing number of disabled people unable to leave their homes The Guardian https://www.theguardian.com/society/2017/mar/15/disabledpeople-suffer-inaccessible-social-housing

(Last accessed 2 May 2018)

Savage, M. (2015) Social Class in the $21^{\text {st }}$ Century London, Pelican books

Sentamu, J. (2014) 'Foreword by the Archbishop of York' in Sentamu, J. Working for Poverty: The scale and problem of low pay and working poverty in the UK London, Living Wage Commission

Shildrick, T. (2017, February 1) 'Poverty, politics and a new kind of class war?' Discover Society $1^{\text {st }}$ February 2017 https://discoversociety.org/2017/02/01/poverty-politics-and-anew-kind-of-class-war/

(Last accessed 2 May 2018)

Shildrick, T. (2018) Poverty Propaganda: Exploring the myths Bristol, Policy Press 
Shildrick, T. (2018 forthcoming) Poverty in Britain: Causes, consequences and myths Bingley, Emerald

Shildrick, T. and MacDonald, R. (2013) 'Poverty talk: how people experiencing poverty deny their poverty and why they blame the poor' The Sociological Review 61, 2, pp285-303

Shildrick, T., MacDonald, R., Furlong, A., Roden, J. and Crow, R (2012b) Are cultures of worklessness passed down the generations York, JRF

Shildrick, T., MacDonald, R., Webster, C., Garthwaite, K. (2012a) Poverty and Insecurity: Life in low pay, no pay Britain Bristol, Policy Press

Smyth, D. (2017) Obituary: Khajida Saye, fast rising artist killed tragically young in Grenfell Tower British Journal of Photography http://www.bjp-online.com/2017/06/obituarykhadija-saye-grenfell-tower/Accessed

(Last accessed 2 May 2018)

Springfield, F. (2017) Grenfell Tower - Neglect of the most vulnerable https://www.huffingtonpost.co.uk/fran-springfield/grenfell-towerneglect b 17239116.htmlAccessed

(Last accessed 2 May 2018)

Taylor-Gooby, P. (2013) The Double Crisis of the Welfare State and What We Can Do About It Basingstoke, Palgrave MacMillan

Taylor-Gooby, P. (2017) 'ReDoubling the Crises of the Welfare State: The impact of Brexit on UK welfare politcs' Journal of Social Policy Vol. 46 (4) pp 815 - 836 
Trust for London (2017) London's poverty profile London

https://www.trustforlondon.org.uk/data/boroughs/kensington-and-chelsea/

(Last accessed 2 May 2018)

Tyler, I. (2013) 'The riots of the underclass: stigmatisation, mediation and the government of poverty and disadvantage in the UK' Sociological Research on Line 18 (4), 6

Tyler, I. (2015) 'Classificatory struggles: class, culture and inequality in neoliberal times' in The Sociological Review Vol. 63 (1) pp493 - 511

Tyler, I. (2017) 'The hieroglyphics of the border: Racial stigma in neoliberal Europe Ethnic and Racial Studies online August 2017

http://www.tandfonline.com/doi/full/10.1080/01419870.2017.1361542

UN Economic and Social Council, Committee on Economic and Social Rights (2016)

Concluding observations on the sixth periodic report of the United Kingdom of Great Britain and Northern Ireland, E/C.12/GBR/CO/6, http://tbinternet.ohchr.org/layouts/treatybodyexternal/Download.aspx?symbolno =E\%2fC. $12 \% 2 f G B R \% 2 f C O \% 2 f 6 \&$ Lang=en

(Last accessed 2 May 2018)

Walker, P. (2018, March 22) 'Tories will break pledge to rehouse Grenfell survivors says Javid' The Guardian 
Watt, P. (2017) "This place is post-something': London's housing in the wake of the Grenfell Tower fire City Analysis blog http://www.city-analysis.net/2017/06/23/this-place-ispost-something-londons-housing-in-the-wake-of-the-grenfell-tower-fire-paul-watt/

(Last accessed 2 May 2018)

Welshman, J. (2013) Underclass: a history of the excluded since 1880, London: Bloomsbury Press

Wilkinson, R. and Pickett, K (2010) The Spirit Level London, Penguin

Wright, S. (2016) Conceptualising the active welfare subject: Welfare reform in discourse, policy and lived experience. Policy and Politics, 44, 235-252

\section{Biography}

Tracy Shildrick is Senior Lecturer at Newcastle University. She has researched and published widely in the areas of poverty, disadvantage and youth. Her co-authored book with Policy Press, Poverty and Insecurity: Life in low pay, no pay Britain won the British Academy Peter Townsend prize in 2013 and two new books Poverty Propaganda: Exploring the myths (Policy Press) and Poverty in Britain: Causes consequences and myths (Emerald Publishing) will both be published in April 2018 